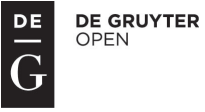

\title{
SOME OF THE THEORETICAL BASIS OF LOCAL SELF-GovernMENT IN THE CZECH REPUBLIC
}

\author{
Petr Pospíšil ${ }^{1}$, Marian Lebiedzik ${ }^{2}$
}

\begin{abstract}
In the valid legislation of the Czech Republic, we do not find a clear and completely unambiguous definition of the concept of "self-government". Nonetheless, it is an institute traditionally used and with content defined in a particular way by the theory of administrative law or administrative science in the context of the division of public administration into state administration and self-government. Self-government usually refers to public administration (i.e. administration of public affairs) carried out by public law bodies other than the state. These public law bodies are most often public corporations, which perform specific tasks within territorial self-government, professional self-government and interest group self-government. The aim of the paper is to provide an interpretation of the theoretical and legislative definition of the concept of self-government and specifically to focus on territorial self-government. In processing the paper and fulfilling the set goal, the authors will primarily use scientific methods of analysis, synthesis, description, explanation and comparison. Based on the presentation and analysis of theoretical opinions on the issue, the applicable legislation of territorial self-government and insights from public law-related practice, the authors conclude that it is appropriate to consider a more detailed (yet open) definition of self-governing tasks of municipalities and regions in the future.
\end{abstract}

\section{Keywords}

Czech Republic, Public Administration, Self-government, Territorial Self-government, Territorial Self-governing Units, Municipalities, Regions

\section{Introduction}

The end of 2015 completed 15 years of the existence and functioning of the regions as representatives of a higher (supra-local) level of territorial self-government in the

\footnotetext{
${ }^{1}$ Silesian University in Opava, School of Business Administration in Karviná, Univerzitní nám. 1934/3, 73340 Karviná, Czech Republic. E-mail: pospisil@opf.slu.cz.

${ }^{2}$ Silesian University in Opava, School of Business Administration in Karviná, Univerzitní nám. 1934/3, 73340

Karviná, Czech Republic. E-mail: lebiedzik@opf.slu.cz.
} 
Czech Republic. This is a good opportunity to reflect on the selected model of public administration and evaluate its existing operations. Furthermore, based on this paper, the authors want to look back at the 15-year existence of municipalities.

The legal basis of restoring the real territorial self-government was laid on 18 July, 1990, by the Federal Assembly of the Czech and Slovak Federal Republic by adopting the Constitutional Act N. 294/1990 Coll., which amends and supplements the Constitutional Act N. 100/1960 Coll., the Constitution of the Czechoslovak Socialist Republic and the Constitutional Act N. 143/1968 Coll., on the Czechoslovak Federation, and which reduces the concept of the National Committees. Chapter 7 of the amended Constitution, titled "Local Self-Government", went back to the traditional way of finding that "the foundation of local self-government is a municipality" arising from the Reich Municipal Act N. 170/1849 of the Reich Code, and laid down the basic principles for the functioning of local self-government. Immediately after the constitutional anchoring of local selfgovernment, the Czech National Council adopted on 4 September, 1990, Act N. 367/1990 Coll., on Municipalities (Municipal Establishment), which took effect on 24 November, 1990, and brought a detailed legal amendment of the activities of the municipality and its authorities. However, the higher level of territorial self-government was mentioned only in the Constitutional Act N. 1/1993 Coll., the Constitution of the Czech Republic, as amended (hereinafter referred to as the "Constitution of the CR") and its actual establishment took place based on the Constitutional Act on 3 December, 1997, N. 347/1997 Coll., on the Establishment of Higher Self-governing Units and amendment of the Constitutional Act of the Czech National Council N. 1/1993 Coll., the Constitution of the Czech Republic until 1 January, 2001. ${ }^{3}$

The objective of this paper is to provide an interpretation of the theoretical and legislative definition of the concept of self-government, and specifically to focus on territorial selfgovernment. Based on the presentation and analysis of theoretical opinions on the issue, the applicable legislation of territorial self-government and insights from public law practice, the authors want to confirm or refute the hypothesis that the current definition of selfgoverning tasks of municipalities and regions corresponds to the needs of public law practice.

\section{The relevance of the topic}

Fulfilling the concept of local self-government was part of a reform effort in the Czech Republic after 1990 that took place in varying degrees in all post-communist countries of Central and Eastern Europe. ${ }^{4}$ The so-called mixed model of local governance in the Czech Republic was selected for the functioning of local government and regional government, particularly with regard to the historical tradition. In this model, local government units in the area are governed both by state and local governments. ${ }^{5}$ After the dissolution of district authorities in 2002, state authorities with general competence disappeared in the

\footnotetext{
${ }^{3}$ Pospíšil (2007).

${ }^{4}$ Yoder (2003).

${ }^{5}$ Průcha (2008).
} 
territory. ${ }^{6}$ However, the public administration reform implemented in the Czech Republic has not yet been completed. Preference has always been given primarily to the local public administration reform, while the reform of central government as a whole has, in fact, not yet been implemented. This is also stated in the official materials of the Ministry of the Interior, which is in charge of planning the reform of public administration. ${ }^{7}$

The mixed model of public administration has gradually been accompanied by some problems, e.g. in the current issue of so-called systemic prejudice, which has been mainly defined by case law in recent years. Municipalities and regions perform both independent and delegated powers. It may therefore easily happen that in one set of proceedings a petitioner or applicant along with the decision-making body are the same. There are legitimate doubts about the impartiality of public officials in such a situation. These people can be influenced in different ways by their employer (the municipality or region as parties) in their decisions. Only in connection with the issue of systemic prejudice has the possibility lately been discussed of changing the system of public administration in the Czech Republic, which consists of the institutional separation of state and local government at the local level. ${ }^{8}$

The controversy over the content of the legal basis of the concept of self-government is still ongoing. In the following article our aim is to contribute to this debate.

\section{Generally on the concept of "self-government"}

The Constitution of the Czech Republic and other legal regulations do not contain a clear and precise definition of the concept of "self-government". Nevertheless, it is the concept traditionally used and its content is defined in a particular way by the theory of administrative law or administrative science in the context (simply said) of a classic bipolar division of public administration into state administration and self-government. As aptly expressed by Sládeček: "As far as the present is concerned, we usually come upon the concept of self-government particularly in the field of administrative law when referring to the basic division of public administration into administration performed by state authorities, i.e. state administration and self-government, which is provided by public law, non-state authorities." ${ }^{\prime 9}$ Self-government therefore typically means public administration (administration of public affairs) carried out by public law authorities other than the state. The fact that the state is willing to confer part of its powers within the exercise of public administration on authorities, over which it does not have direct control, is an important feature of a democratic society. Obviously, the state always keeps control over self-government (both territorial self-government and interest group self-government) as it possesses legislative power allowing some interventions in the activities of self-government authorities through law amendments or even decisions on abolishing self-government authorities in the context of a specific step in the reform.

\footnotetext{
${ }^{6}$ Havlan, Janeček (2016).

${ }^{7}$ Ministry of the Interior (2012).

${ }^{8}$ Bursíková (2011).

${ }^{9}$ Sládeček (2004).
} 
The Constitutional Court of the Czech Republic expressed its opinion on the issue of the legislator's intervention into self-government as follows: "The guarantee of territorial selfgovernment under the Constitution of the Czech Republic is laconic... The right of selfgovernment generally expressed by the Constitution shall not be emptied by the legislator, however, it is evident, that the legislator has a wide space for specifying the matters that are best managed at the municipal or local level without any greater interference by the central state authority". ${ }^{10}$ Self-government is thus a form of a decentralization of (state) administration of public affairs and its existence brings "checks and balances" to the democratic political system. ${ }^{11}$

Self-government as an example of the decentralization of state administration is also recognised by Hoetzel, who lists the following benefits of self-government: "local and factual peculiarity, oddity of circumstances and needs, the rise in the understanding of the tasks, and issues of public administration, political education of the population, division of responsibility for public life between the state and self-government associations..." Hoetzel further stresses the need to distinguish between the political and legal concept of self-government. According to Hoetzel, the political concept means "merely an organizing principle of state administration: state administration is not only provided by officials by profession but also civil persons - compare the district school board and provincial school board..." Also, the legal concept of self-government means that "it is provided by someone else other than the state, i.e. the public law association, as there is no individual self-government in this country... " 12

Průcha connects self-government with "the authorization to create self-governing power", whilst defining it as "organizing and power - protective actions of territorial and selfgoverning interest group corporations and their authorities in the specifically power conception, extended by the authorization to create self-governing power of sub-statutory and regulatory nature, which takes place in relationships; on the one hand self-government authorities act there and are involved in this activity, and on the other hand, there are entities in their jurisdiction, however whose scope of activity lacks the essence of state power." 13

Self-government is exercised by authorities known as public law corporations (see also below), which are entrusted with the performance of certain tasks, within territorial self-government or professional self-government or interest group self-government. It is possible to encounter classification according to which self-government is divided into

\footnotetext{
${ }^{10}$ Compare the Judgment of the Constitutional Court of 5 February, 2003, published under N. 53/2003 Coll.

${ }^{11}$ Checks and balances (Engl. checks and balances, Fr. freins et contrepoids, Ger. Hemmungen und Gegengewichte; however, in German, the concept of "checks and balances" is mostly applied) refers to a mechanism, which provides for the system of the division of power, in which none of the branches of state power (i.e. the legislative, executive and judicial branches of the government) would receive privileged position and thus jeopardize the democratic nature of the political system. The author of this concept of checks and balances is Charles Montesquieu (1689-1755), who outlined this concept in his book The Spirit of the Laws (De l'esprit des lois, 1748).

${ }^{12}$ Hoetzel (1938).

${ }^{13}$ Průcha (2002).
} 
territorial, professional, academic and economic self-government. ${ }^{14}$ Public administration delegated to these entities is naturally separated from state administration, both in terms of a substantive and procedural view. However, this separation of self-government and state government cannot be absolute - inter alia without turning self-government into anarchy, whilst observing the necessary procedures, i.e. a certain degree of certainty of the recipients of the public law regulation in cases when decisions on the rights and obligations of natural and legal persons in the performance of self-government are made. Having mentioned the above branches of self-government, attention will subsequently only be paid to territorial self-government in this paper.

\section{Territorial self-government in the Czech Republic and its constitutional anchoring}

Territorial self-government is an expression of the right and competence of local (or regional) authorities to manage public affairs within the limits of the law, under their own responsibility and in the interests of the local population (or population of the region). In this context, the Constitutional Court of the Czech Republic held that “. . local selfgovernment is an expression of the right and competence of local authorities within the limits of the law, under their own responsibility and in the interests of the local population to control and manage part of public affairs. According to the initial proposition, on which the concept of self-government is constructed, the basis for the free state is a free municipality, then it is the region at a higher level of the territorial hierarchy of the selfgoverning community of citizens under the Constitution from the perspective of the regional importance... territorial self-governing units, representing the territorial community of citizens, must have - through autonomous decision making of their representative authorities - the freedom to decide in a free manner on how to dispose of the funds, with which self-governments are provided for meeting the challenges of self-government. The management of their property independently on their own account and responsibility is an attribute of self-government." 15

Hoetzel sees the essence of self-government as "a kind of microcosm of the state: it is the universality of competence and authoritarian power, all persons are subject to the municipality and through them all the stuff on its territory." 16 Hoetzel's perception is certainly immanent in the present two tier-arrangement of territorial self-government in the Czech Republic, although there is a middle level of the "regional mesocosm" between the "local microcosm" and the "state macrocosm", with both mentioned levels of selfgovernment, which have been built on similar principles. Indeed, this corresponds to Englišs's finding that "such a bond (of self-government) shall look after the specific task, which manages it as cost-effectively as possible."17

For instance, Peková expresses herself to the position of territorial self-government as follows: "In democratic countries territorial self-government is a non-state authority

\footnotetext{
${ }^{14}$ Filip (1999).

${ }^{15}$ See the Judgment of the Constitutional Court of the CR published under N. 211/2006 Coll.

${ }^{16}$ Hoetzel (1938).

${ }^{17}$ Engliš (1946).
} 
and is usually significantly independent on the state. One of the few tools the state may influence decision-making of local self-government is legislation, regarding economic tools they involve indirect tools - particularly financial tools - the basic rules of budget management set by the legislation, further the set budget determination of taxes, the rate of tax power of territorial self-government, subsidiaries and criteria for their granting from the state budget to the budgets at the different levels of self-government." 18

Territorial self-governing units have the status of a legal person and appear thus in legal relations under their own name, act under their own responsibility and at the same time they dispose of financial resources and own property under their own name, whilst articulating accordingly the economic basis of territorial self-government, ${ }^{19}$ and constituting key elements of local self-government, together with the personal basis represented by a selfgoverning community of citizens and territorial basis represented by the territory, on which self-government is implemented by the given community of citizens. As reported by Mates, "territorial self-government has been with us for more 160 years legally defined by three characters, namely the territory, population and performance of (independent) administration along with the fact that it is a corporation with its own personality and property." 20

Territorial self-governing units (i.e. at present municipalities and regions in the Czech Republic) represent then public law corporations, according to Hendrych "member organized entities of public administration, who were entrusted with the power to perform public tasks independently". ${ }^{21}$

According to Art. 8 of the Constitution of the CR, the autonomy of territorial self-governing units is guaranteed. The details concerning the constitutional framework of territorial selfgovernment are then described in Chapter 7 of the Constitution of the Czech Republic titled literally "Territorial Autonomy". The Czech Republic is divided into municipalities, which are the basic territorial self-governing units. Higher territorial self-governing units are regions; based on the amendment to the Constitution of the CR, the earlier uncertainty was superseded as to whether regions or lands would be established. ${ }^{22}$ Territorial self-governing units are territorial communities of citizens who have the right to self-government. The law stipulates when they are administrative districts. The municipality is always part of a higher territorial self-governing unit. Establishing and abolishing a higher territorial self-governing unit can be only implemented by the Constitutional Act.

\footnotetext{
18 Peková (2007).

${ }^{19}$ Kadečka (2009)

${ }^{20}$ Mates (2011).

${ }^{21}$ Hendrych et al. (2006).

22 The Constitution of the CR, adopted by the Constitutional Act N.1/1993, Coll., originally anchored that higher territorial self-governing units were lands or regions, and establishing and abolishing the territiorial higher selfgoverning units can only be executed by the Constitutional Act. The formation of regions as higher territorial self-governing units and simultaneously the elimination of the concept of the "land" from the Constitution followed on the basis of the Constitutional Act N.347/1997 Coll., on the Establishment of Higher Territorial Self-governing Units and on the amendment of the Constitutional Act of the Czech National Board N. 1/1993 Coll., the Constitution of the Czech Republic.
} 
The constitutional anchoring of the territorial self-government is commented by Hendrych as follows: "The Constitution of the CR stipulates that the autonomy of self-governing units is guaranteed (Art. 8 of the Const.), the content of self-government itself, i.e. the sphere of tasks of public administration, which municipalities and regions should perform in their own name, however, does not define." 23

According to the Constitution of the CR, territorial self-governing units are independently managed by the Council. The competence of Councils (municipalities and regions) may be only stipulated by the law. Art. 104 Sec. 2 of the Constitution of the CR deals in the most general manner with the division of competences between the municipal Council and municipality of a higher territorial self-governing unit, as it determines that the municipal Council shall decide in matters of self-government, unless they are entrusted by the law with the Council of a higher territorial self-governing unit. This has to do with the principle of subsidiarity in public administration. As explained, e.g. by Koudelka: "Public power has to be therefore represented by the closest element to the citizen . . However lower units cannot make decisions on matters that concern them, yet they have a higher (regional, land, state) dimension. The railway, motorway, airport serve higher social units, and therefore the interests of a lower unit (municipality) cannot be decisive." ${ }^{24}$ Councils of (municipalities and regions) may, within the limits of their competence, issue generally binding public notices. In addition to the powers of the municipal Council (municipality and region) to issue generally binding public notices within its independent competence, the Constitution of the CR in Art. 79 Section 3 (systematically included in Chapter 3 titled "Executive Power") enables territorial self-government authorities (besides ministries and other administrative offices) to issue legal regulations on the basis and within the limits of the law unless they are empowered by the law to do so. With regard to the authorization of higher territorial self-governing units to issue legal regulations, we shall not disregard Art. 41 Section 2 of the Constitution of the CR (systematically included in Chapter 2 titled "Legislative Power"), which authorizes the municipal Council of the higher territorial self-governing unit (besides an MP, a group of MPs, the Senate and the Government) to submit a bill to the Chamber of Deputies. ${ }^{25}$

Members of Councils of (municipalities and regions) are elected by secret ballot on the basis of universal, equal, and direct right to vote. The functional competence of the Council (municipality and region) is four years. The law lays down the conditions under which new elections to the Council will be announced before the expiry of its functional competence. In this context, it can be noted that, during the period of 15 years of the functioning of regions as higher territorial self-governing units, the practice has brought about several major confrontations between the state and regions, the nature of which was the different perception of the legitimacy of state interference in the activities of regions. ${ }^{26}$ Thus the following

\footnotetext{
${ }^{23}$ Hendrych et al. (2006).

${ }^{24}$ Koudelka (2007).

25 Kadečka (2003).

${ }^{26}$ Obviously, it is not the case of disputes of municipalities and regions and the state. As far as the mentioned issue of health care is concerned, it also applies to municipalities which are promoters of health centers. An example of disputes between the state and municipalities are also changes in the budgetary allocation of taxes that confronts not only the state and territorial self-governing units, but even regions and municipalities and
} 
may be stated, e.g. a different perspective on the issues of health centers ${ }^{27}$ established by the region (and also municipalities). However, it has to be pointed out that these disputes are much more of a political than legal nature, since they mostly stemmed from the fact that different political parties "ruled" at the central and regional level and the "disputes over self-government" (its content and scope) became part of the permanent political struggle. The appropriate "breeding ground" for these disputes is undoubtedly the above implied and somewhat insufficient, content-impalpable concept of "self-government" in the valid legislation. In the legal regulation of territorial self-government in the Czech Republic, currently two primary (and understandable) tendencies can be clearly traced: namely, the efforts of municipalities and regions on strengthening their authorization in their independent competence at the expense of the transferred execution of state administration; by contrast, there are apparent efforts by the state to extend, or at least maintain its influence over the functioning of territorial self-government. ${ }^{28}$

It is also worth mentioning the provisions of Article 87 Section 1 of the Constitution of the $\mathrm{CR}$, which define the competence of the Constitutional Court and (fully in accordance with its basic role of a protector of constitutionality) lay down inter alia that the Constitutional Court makes a decision:

- According to Letter c) on the constitutional complaint of authorities of territorial self-government against the unlawful intervention of the state,

- According to Letter $\mathrm{k}$ ) on the disputes over the scope of competences of government bodies and territorial self-government authorities, if not entitled under the law to another authority.

The basic constitutional principles limiting the performance of state administration also apply to the performance of territorial self-government, which are identically defined in Art. 2 Section 3 of the Constitution of the CR and in Art. 2 Section 2 of the Charter of Fundamental Rights and Freedom. According to this generally accepted rule, state power serves all citizens and can be exercised only in cases, within the limits and methods, which are determined by the law. From the judicial decisions of the Constitutional Court, it follows that territorial self-governing units are limited by cited provisions in those cases, when exercising their public power in independent competence. ${ }^{29}$

\section{Tasks of territorial self-governing units in the Czech Republic}

The characteristic feature is that in the activities of regions and municipalities, the public and private principles are inextricably intertwined and mutually affected. The fuzzy boundary between public and private law has also been addressed by the Supreme Court of the Czech Republic: "Between legal regulations of public and private law, then between public and private law a sharp boundary cannot be kept also because many legal regulations of

cities and other municipalities.

${ }^{27}$ Pospíśil (2005).

${ }^{28}$ Vedral (2006).

${ }^{29}$ Compare the Judgment II of Const. Court 75/93, the Collection of Judgments and Resolutions, vol. 2, p. 201. 
private law include rules of the public law nature and, conversely, public law legislation often requires the application of the institutes of private law."30

It generally applies that territorial self-governing units have, together with the state, in the economic (entrepreneurial) environment a specific position. Territorial self-governing units have their tasks (mission) defined in rules that are inherently public law rules. As it is evident, e.g. from the definition of independent competence of the region and municipality in the Act N. 129/2000 Coll. on Regions (Regional Establishment) as amended, (hereinafter referred to as the "Region Act") and in the Act. no. 128/2000 Coll. on Municipalities (Municipality Establishment), as amended, (hereinafter referred to as the "Municipality Act") the primary concern of the municipality (region) is not to operate on the market and make a profit, but rather meet the needs of its citizens. ${ }^{31}$ The dominant role of regions and municipalities (but naturally also the state) lies mainly in the provision of services of public interest, referred to as publicly beneficial activities. Indeed, the tasks of cities in a different legal environment, such as in the USA, are based on a similar principle. As reported by Glaeser: "American local governments own and manage a wide portfolio of enterprises, including gas and electricity companies, water systems, subways, bus systems and schools." 32 Typical areas where territorial self-governing units traditionally implement their own independent competence are, in the Czech Republic, e.g. social services, health service, education, culture or transport. According to Pokorná: "these are such relationships, when a certain public need is provided for. Enumerating these areas is completely impossible as they extend into diverse areas such as defense, national security, culture, education, the environment, social and health security and many, many more." 33 The positive Czech legislation approaches the definition of the self-governing competence of territorial self-governing units in a somewhat minimalist manner. This minimalist approach is based on historical traditions, as a similar general definition of independent competence was already included in the general Reich Local Government Act for the Cisleithanian Lands N. 18/1862 of the Reich Code, which in its Art. IV defined independent competence "in which a municipality, whilst observing Reich and provincial laws, may freely adopt provisions and ordain accordingly, as well as take measures to the benefit of the municipality and within the limits of its own power and execution." The relevant provisions of the Act on Municipalities and the Act on Regions do not contain any enumeration of self-governing tasks, which the municipality (region) should perform. The content of these self-governing tasks is concretized by referring to some of the provisions

\footnotetext{
${ }^{30}$ Compare the Judgment of the Supreme Court 32 Odo 1104/2005 of 9 November, 2006.

${ }^{31}$ Compare the provisions 14 of paragraph 1 of the Act on Municipalities: Independent competence of the region involves matters, which are in the interests of the region and citizens of the region, if it is not the case of delegated powers of the region. ... and the provisions 35 of paragraph 1 of the Act on Municipalities: Independent competence of the municipality involves matters, which are in the interests of the municipality and citizens of the municipality, unless they are delegated to the regions by the law or if it is not the case of delegated powers of municipality authorities or competence, which, by special law, is entrusted to administrative authorities as an execution of state administration and further matters entrusted by the law to the independent competence of the municipality.

32 Glaeser (2001).

33 Pokorná et al. (2009).
} 
of the Act on Municipalities (Regions), in particular those defining the competence of the Council and Board. Apart from the Act on Regions and the Act on Municipalities, evidently, self-governing tasks of territorial self-governing units can also be found virtually in a large number of special laws governing the competence of public authorities in the different branches - e.g. in health care, social affairs, education, heritage preservation, waste management, roads, etc. In addition to these, the general proposition holds true that "matters pertaining to independent competence of the municipality (region), are of interest of the municipality (region) and citizens of the municipality (region)." The Act on Municipalities in provisions 35 of paragraph 2 gives at least "sectoral guidance" on the content of the concept of self-government when establishing that: "The municipality in independent competence in its local district still in compliance with local preconditions and local customs takes care of creating conditions for the development of social welfare and for meeting the needs of its citizens. It is mainly about meeting the needs for housing, protection and development of health, transport and communications, the needs for information, training and education, the overall cultural development, and the protection of public order." ${ }^{34}$ Regarding the looser definition of the concept of self-government in the Czech legal order, the scope of self-government is therefore not entirely clear, i.e. an unambiguous definition of what already is (still) / is (not) in the interests of the municipality (region) and its citizens, i.e. what already can (cannot) be (still) legitimately considered a performance of the self-government of the municipality (region).

Vedral expressed himself critically on the definition of self-governing tasks in provisions 35 of paragraph 2 of the Act on Municipalities: "Even in this section the content of the provisions 35 of paragraph 2 suggests a certain improvisation and not very clear conception when defining the scope of independent competence, both in that the creation of conditions for: 'the development of social welfare and meeting the needs of citizens of the municipality' is juxtaposed, although social welfare belongs to 'the needs of citizens of the municipality' as well as in the content of the illustrative list of individual 'needs' of citizens of the municipality, where 'the need for housing', 'the need for information' and 'the need for public order' are put next to each other in one sentence." 35

Sotolár perceives the issue of the content of self-government as follows: "The content of self-governing functions (tasks) is, from the practice point of view, desirable to divide into two relatively separate areas: functions and tasks of the municipality in the area of the performance of public administration and economic activity of the municipality. In the first area the municipality acts as a holder of power and entity of public administration. On this basis, it uses its sovereign authority, evidently whilst observing the limits stipulated by the Constitution of the Slovak Republic, the Charter of Fundamental Rights and Freedom and Laws. In the second area the municipality has a status of an ordinary 'legal person'

\footnotetext{
${ }^{34}$ The Act on Regions contained a similar provision, only until 31 December, 2002, as it was omitted through the amendment of the Act. N. 231/2002 Coll. In the explanatory memorandum to the draft amendment to this change, it somewhat incomprehensively states that: It is a more precise diction and compliance with the Act on the capital City of Prague. Compare the explanatory memorandum to the draft amendment on regions, accessible at ASPI ID LIT23880CZ.

${ }^{35}$ Vedral et al. (2008).
} 
with the same rights and obligations as other legal entities. It is then a legal entity of private law and provides for performing double tasks through means of private law (e.g. in investment activities, when implementing business activities, etc." ${ }^{36}$

Sotolár certainly gives his opinion on Slovak legislation, in which, compared to the Czech minimalist approach, the Slovak legislator opted for the opposite approach and those matters considered the performance of self-government are provided in great detail in the form of an exemplary list directly in legal regulations governing the status and activity of territorial self-governing units. In the context of the definition of self-governing competence of the municipality (region), the Slovak regulations explicitly mention the following, e.g. "the provision of construction and maintenance of communications, management of municipal waste, water supply, creating conditions for the provision of health care, the performance of one's own investment and business activities in the interest of meeting the needs of the population of the municipality and its development, etc." ${ }^{37}$ What is essential is that these legislative enumerations of self-governing tasks of Slovak municipalities and regions are demonstrative (open), i.e. they do not preclude the fulfilment of other tasks, which are not listed here, and which may occur in practice. Slovak legislation may be of specific guidance for the Czech legislator when considering the specification of the definition of self-governing tasks of territorial self-governing units in the relevant laws. On the other hand, it is necessary to agree with Koudelka, who claims that: "Self-government cannot be set preconceived limits, since the concept of local interests is constant in time. Therefore, independent competence cannot be determined enumaratively." 38

\section{Conclusion}

In the valid legislation in the Czech Republic, we do not find a clear and completely unambiguous definition of the concept of "self-government". Nonetheless, it is the institute traditionally used and with content defined in a particular way by the theory of administrative law or administrative science in the context of the division of public administration into state administration and self-government. Self-government usually refers to public administration (i.e. administration of public affairs) carried out by public entities other than the state. These other public entities are most often public corporations, which perform specific tasks within territorial self-government, professional self-government and interest group self-government. In the submitted paper, more attention has been paid to the issue of territorial self-government, which is the expression of the law and competence of local (or regional) authorities disposing of legal subjectivity to manage public affairs within the limits of the law, under their own responsibility and in the interests of the local population (or population of the region).

In terms of the confirmation or refutation of the hypothesis set out in the introduction, it can be concluded that the model set up in principle corresponds to the needs of public

\footnotetext{
${ }^{36}$ Sotoláŕ (2011).

${ }^{37}$ Compare the provisions 4 of paragraph 3 Letter a) to s) of the Act of SNR N. 369/1990 Coll., on Municipalities, as amended, and similarly the provisions 4 of the Act N. 302/2001 Coll., on Self-Government of Higher Territorial Self-governing Units (the Act on Self-Governing Regions), as amended.

${ }^{38}$ Koudelka (2007).
} 
law practice. This content, impalpable concept of "self-government" brings with it quite particular difficulties in the Czech Republic, manifested mainly in disputes between the state and self-governing power, in which it has to do mostly with the boundaries (limits) in the terms of the legitimacy of interventions of state power into self-government. The minimalist approach of the Czech legislator is just playing into the hands of the disputes in terms of the definition of self-governing tasks of municipalities and regions, and is specified by reference to the provisions of the Act on Municipalities and the Act on Regions, which define the competence of the Council and Board. In these disputes, selfgoverning entities (both territorial and interest group self-government) always get the short end of the stick rather than the state just because it has the legislative power, which can intervene in the activities of self-governing entities in the form of law amendments, or even decide to abolish self-governing entities in the context of a specific step of the reform. As regards the definition of self-governing tasks of municipalities and regions, in line with the intentions of the above, we can consider de lege ferenda of a certain inspiration by the Slovak model resting on the more detailed, but still open legislative enumeration of self-governing tasks of municipalities and regions, which does not exclude all possible non-mentioned self-governing tasks, which the practice may bring about. Through such a modification, some friction between the state and self-government could be reduced as a result of a more precise definition of the content and scope of self-government, i.e. what already is (still) / is (not) in the interests of the municipality (region) and its citizens, i.e. what already can (cannot) be (still) legitimately considered a performance of the selfgovernment of the municipality (region).

\section{References}

Bursíková, E. (2011). Podjatost úředníků územních samosprávných celků. Sborník z V. ročníku mezinárodní konference Dny práva. Brno: Právnická fakulta Masarykovy univerzity. Engliš, K. (1946). Malá finanční věda (2nd ed.). Prague: Nakladatelství Fr. Borový.

Filip, J. (1999). Ústavní právo 1, Základní pojmy a instituty, Ústavní základy ČR (3rd ed.). Brno: Masarykova univerzita v Brně a nakladatelství Doplněk.

Glaeser, E. L. (2001). Public ownership in the American city. Cambridge: National bureau of economic research.

Havlan, P., Janeček, J. (2016). Territorial Self-Governing Units of the Czech Republic as Entities Possessing Ownership and Other Proprietary Rights. DANUBE: Law and Economics Review, 7(2), 105-121.

Hendrych, D. et al. (2006). Správní právo, Obecná část (6th ed.). Prague: C. H. Beck. Hoetzel, J. (1938). Heslo „Samospráva“. In Slovník veřejného práva československého, Svazek IV. (S až T). Brno: Nakladatelství - Polygrafia - Rudolf M. Rohrer - Brno. Reprint původního vydání, EUROLEX BOHEMIA, s. r. o., Prague: 2000.

Kadečka, S. (2003). Právo obcí a krajů v České republice. Prague: C. H. Beck.

Kadečka, S. (2009). Ekonomický aspekt územní samosprávy. In Kadečka, S. (ed.). Pocta Petru Průchovi. Prague: Vysoká škola aplikovaného práva.

Koudelka, Z. (2007). Samospráva. Prague: Linde Prague, a. s. 
Mates, P. (2011). Státní dozor nad zájmovou samosprávou. Právní rozhledy, 24, 885-889. Ministerstvo vnitra. (2012). Koncepce dokončení reformy veřejné správy.

Peková, J. (2007). Finanční aspekty reformy územní samosprávy v ČR. In Reforma veřejné správy. Sborník př́spěvků. Prague: ASPI, a. s.

Pokorná, J. et al. (2009). Obchodní zákoník. Komentář. II. díl (§ 221 až 775). Prague: Wolters Kluwer ČR, a. s.

Pospíšil, P. (2005). Krátká úvaha o souvislostech dvou poslaneckých návrhů právních předpisů. Zdravotnictví a právo, 1(18).

Pospíšil, P. (2007). Krajská (regionální) samospráva od historie k současnosti. Správní právo, 4-5, 234-251.

Průcha, P. (2002). Heslo „Samospráva“. In Průcha, P., Pomahač, R. Lexikon - správní právo. Ostrava: Nakladatelství Jiří Motloch - Sagit, s. r. o.

Průcha, P. (2008). K otázkám organizace současné místní a regionální samosprávy. In Sborník z II. ročníku mezinárodní konference Dny práva. Brno: Právnická fakulta Masarykovy univerzity.

Sládeček, V. (2004). Obecné správní právo. Prague: ASPI, a. s.

Sotoláŕ, J. (2011). Samospráva obce. Obecné zriadenie na Slovensku. Košice: SOTAC, s. r. o.

Vedral, J. (2006). Právní úprava postavení územních samosprávných celků (k ideovým zdrojům právní úpravy územní samosprávy v České republice). Právník, 1(10).

Vedral, J. et al. (2008). Zákon o obcích (obecní zř́izení). Komentář. Prague: C. H. Beck.

Yoder, J. A. (2003). Decentralisation and Regionalisation after Communism: Administrative and Territorial Reform in Poland and the Czech Republic. Europe-Asia Studies, 55(2), 263-286. 